\title{
PEMT wt Allele
}

National Cancer Institute

\section{Source}

National Cancer Institute. PEMT wt Allele. NCI Thesaurus. Code C104966.

Human PEMT wild-type allele is located in the vicinity of $17 \mathrm{p} 11.2$ and is approximately 86 $\mathrm{kb}$ in length. This allele, which encodes phosphatidylethanolamine N-methyltransferase protein, is involved in phosphatidylcholine biosynthesis. 